\title{
Introduction to the coalition theory network special issue
}

Citation for published version (APA):

Bloch, F., Herings, P. J. J., Klaus, B. E., \& Wooders, M. (2011). Introduction to the coalition theory network special issue. Journal of Public Economic Theory, 13(6), 883-884. https://doi.org/10.1111/j.14679779.2011.01530.x

Document status and date:

Published: 01/12/2011

DOI:

10.1111/j.1467-9779.2011.01530.x

Document Version:

Publisher's PDF, also known as Version of record

Document license:

Taverne

Please check the document version of this publication:

- A submitted manuscript is the version of the article upon submission and before peer-review. There can be important differences between the submitted version and the official published version of record.

People interested in the research are advised to contact the author for the final version of the publication, or visit the DOI to the publisher's website.

- The final author version and the galley proof are versions of the publication after peer review.

- The final published version features the final layout of the paper including the volume, issue and page numbers.

Link to publication

\footnotetext{
General rights rights.

- You may freely distribute the URL identifying the publication in the public portal. please follow below link for the End User Agreement:

www.umlib.nl/taverne-license

Take down policy

If you believe that this document breaches copyright please contact us at:

repository@maastrichtuniversity.nl

providing details and we will investigate your claim.
}

Copyright and moral rights for the publications made accessible in the public portal are retained by the authors and/or other copyright owners and it is a condition of accessing publications that users recognise and abide by the legal requirements associated with these

- Users may download and print one copy of any publication from the public portal for the purpose of private study or research.

- You may not further distribute the material or use it for any profit-making activity or commercial gain

If the publication is distributed under the terms of Article $25 \mathrm{fa}$ of the Dutch Copyright Act, indicated by the "Taverne" license above, 


\title{
IntRoduction to the CoAlition Theory NetWork SPECIAL ISSUE
}

\author{
FRANCIS BLOCH \\ Ecole Polytechnique, Paris \\ JEAN-JACQUES HERINGS \\ Department of Economics, Maastricht University \\ BETTINA KLAUS \\ University of Lausanne \\ MYRNA WOODERS \\ President of APET, Vanderbilt University
}

The Association for Public Economic Theory was founded in 1998, three years after the Coalition Theory Network. Since then, APET (see www.apet.net) and CTN (see www.feem-web.it/ctn/) have enjoyed a special relationship based on personal, professional, and scientific connections between members of the two groups. APET and CTN both organize annual conferences with a strong overlap in the programs. Coalition sessions have been included in APET meetings, and many of the papers presented at the CTN workshop deal with public economics. The Coalition Theory Network aims to advance the study of coalitions and networks in economic theory. One area of research where coalitions (and networks) are of great importance is public economics, particularly in the study of collective action. Collective action and coalitional behavior have long been recognized as central parts of public economics; they are of special importance in the theory of local public good and shared-good provision. Networks, which have become a speciality of a number of CTN members, are of far-reaching importance in public economics; social networks may play a role in provision of public goods and discrimination in labor markets, for example. Matching models, which are gaining more and more attention from CTN members, also play a large role in the literature on market design and public policy. Thus, on the tenth anniversary of JPET, the Board of the CTN and the Editors of JPET decided to invite papers from the 14th CTN Workshop held in Maastricht, January 2009, for submission to JPET for consideration for publication. We

Received August 30, 2011; Accepted September 2, 2011.

(C) 2011 Wiley Periodicals, Inc.

Journal of Public Economic Theory, 13 (6), 2011, pp. 883-884. 
are pleased to announce that four papers from this event appear in this issue of JPET.

The first two papers, one by Bettina Klaus, Flip Klijn, and Markus Walzl and the other by Gilles Grandjean, Ana Mauleon, and Vincent Vannetelbosch, treat notions of farsighted stability. Klaus, Klijn, and Walzl treat farsighted stability in the familiar context of roommate markets, while Grandjean, Mauleon, and Vannetelbosch treat pairwise stability (no pair of farsighted players can benefit by changing their relationship with each other). Klaus, Klijn, and Walzl deal with subtle issues of properties of farsighted von Neuman-Morgenstern stable sets and show that a singleton matching is von Neumann-Morgenstern farsightedly stable if and only if the matching is stable. They also show that there exist roommate markets without a von Neumann-Morgenstern farsightedly stable set and a roommate market with a non-singleton von Neumann-Morgenstern farsightedly stable set. Grandjean, Mauleon, and Vannetelbosch return to the issue of whether farsighted and myopic behavior leads to different outcomes in the contexts of various rules for the allocation of value arising from the network. They show that "top convexity" of the value function for a network game is necessary and sufficient for the componentwise egalitarian allocation rule, the set of strongly efficient networks, and the set of pairwise (myopically) stable networks that are immune to coalitional deviations to be equal to the unique pairwise farsightedly stable set. They then show that these results do not necessarily hold in some classic models of social and economic networks.

The paper by Luca Dall'Asta, Paolo Pin, and Abolfazl Ramezanpour deals with complex networks. The authors consider a network in which a "best shot game" is played. In a best shot game, each player has two actions, 0 or 1 , and the best response for a player is action 1 if and only if all his neighbors have chosen action 0 . The game may be one in which each node, for example, decides whether to provide a public good for itself and its neighbors. The authors introduce an implementable mechanism and obtain the remarkable result that, in the limit of infinite time, the mechanism reaches an optimal equilibrium, even when the network structure is unknown to the mechanism designer.

Finally, Sylvie Thoron considers situations where a threshold of cooperation is required before an agreement can be reached. The threshold is defined in terms of the players (or coalitions of players) necessary to reach the threshold rather than, as has become standard, to define a threshold in a cooperative game as a required level of contributions to public good provision. Thoron shows that, for an agreement to be reached, the threshold players may bear a commitment cost that can decrease their benefit from an agreement.

The four papers included in this special issue thus span a large spectrum of models of matching, coalitions, and networks. Relations between APET and CTN will continue to grow, with coalition sessions being organized at the PET12 Taipei meeting. 